\title{
Discharge estimation from planform characters of the Shedhi River, Gujarat alluvial plain: Present and past
}

\author{
AlPa SRIDHAR \\ Department of Geology, The Maharaja Sayajirao University of Baroda, Vadodara 390 002, India.
}

\begin{abstract}
In the absence of long-term hydrologic and streamflow records an understanding of river morphology (present and past) can help delineate changes in magnitudes of water and sediment discharges. The relict drainage system of Gujarat alluvial plain provides an opportunity to reconstruct the palaeochannel morphology-related discharge estimations. In this paper, based on the geomorphological evidence and channel geometry, an attempt has been made to reconstruct the palaeohydrological condition in the Shedhi River during the Holocene. A comparison of the present day channel of the Shedhi River with that of its palaeo counterpart reveals that the former was carrying much higher bankfull discharge $\left(\sim 5500 \mathrm{~m}^{3} \mathrm{~s}^{-1}\right)$ as compared to the present $\left(\sim 200 \mathrm{~m}^{3} \mathrm{~s}^{-1}\right)$. This is attributed to a larger drainage area and enhanced precipitation in the Shedhi River basin.
\end{abstract}

\section{Introduction}

Alluvial rivers are dynamic systems subject to rapid change in channel shape and flow pattern. Water and sediment discharges are the principal determinants of the dimensions of a river channel (width, depth, meander wavelength, and gradient). Physical characteristics of river channels, such as width/depth ratio, sinuosity, pattern (braided, meandering, and straight) are significantly affected by changes in flow rate and sediment discharge (Schumm 1968). Rivers can respond to major changes of water and sediment load primarily by pattern changes. Similarly, river channels adjust to changing discharge which is in turn dependent on basin variables, and therefore a comparison between the attributes of the present and the palaeochannels would reflect the change in the discharge regime over time. Because changes in the alluvial channel cross-section, especially width, may indicate changes in streamflow characteristics, known discharges can be expressed as a simple power relation with channel width (Dury 1976). Many 'underfit' streams flow through much larger valleys and have provoked a number of attempts to use channel characteristics in the reconstruction of former discharges. Geomorphic parameters such as channel patterns, meander wavelengths and palaeochannel dimensions were first used in palaeohydrology by Dury $(1954,1976)$ and Schumm (1968) and were modified subsequently depending upon their area of application (Tinkler 1971; Patton and Baker 1977; Knox 1985, 1988; Williams 1988). The study of palaeo and modern channel dynamics has been carried out for various river basins worldwide (Cremaschi and Marchetti 1995; Amsler et al 2005; Roy and Sinha 2005; Callow and Smetten 2006; Eriksson et al 2006). In the Indian context, quantitative palaeohydrological studies were made in the bedrock Deccan rivers and recently in the alluvial rivers of Gujarat (Kale et al 1994, 2004; Alpa 2007). Since these reconstructions depend on the availability of preserved palaeochannels or parts thereof, the alluvial plains of Gujarat with an array of geomorphic features provides an opportunity to reconstruct palaeohydrological conditions that prevailed beyond the historical record.

Keywords. Channel geometry; palaeomeander; discharge; Shedhi River; Gujarat alluvial plain. 


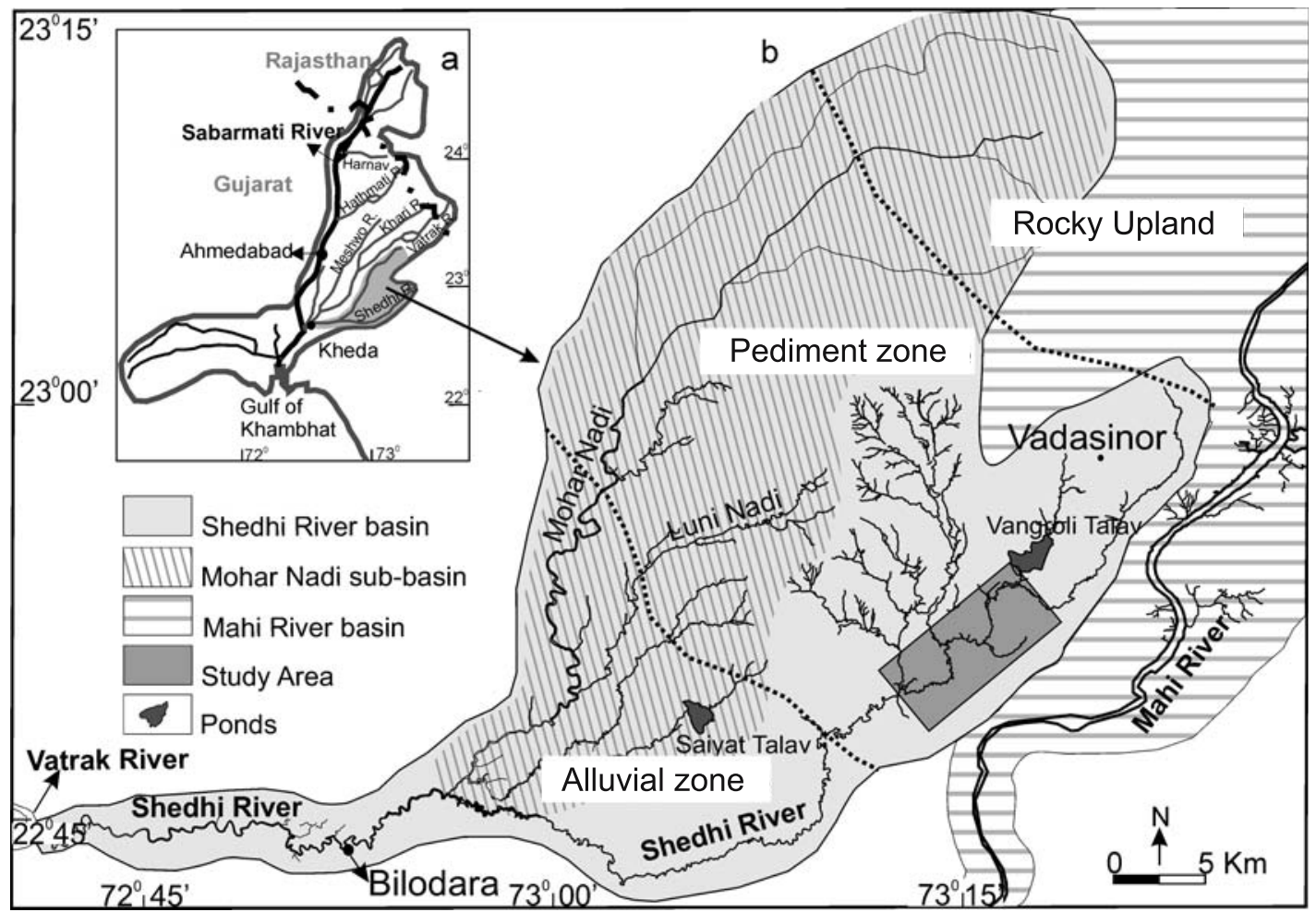

Figure 1. Map showing the study area (a) the Sabarmati River basin and (b) the drainage pattern and major geomorphic zones of the Shedhi River basin.

\section{The Shedhi River}

The drainage of Mainland Gujarat which is controlled by the physiography, lithology, tectonics and climate and the enormous fluvial sedimentation from Pleistocene onwards has been a key factor in the evolution of the alluvial plain. It has been suggested that the present drainage is a relict of a much larger earlier fluvial system operating in the region (Merh and Chamyal 1997). The Sabarmati and the Mahi rivers, in particular, are said to have changed their courses during Holocene (Sridhar et al 1994; Agarwal et al 1996). This is manifested in numerous meander belts, cut-off meanders and abandoned channels between the Sabarmati and the Mahi rivers suggesting the prevalence of a larger fluvial system. In the present study, one such meander belt, through which the present Shedhi River flows, has been investigated for palaeohydrological study. The channel appears to be an 'underfit channel' flowing through a much wider meandering valley. Using the palaeomeander geometry and the other planform characteristics and comparing them with their modern counterparts, an estimation of palaeodischarge has been attempted.

Shedhi River is a third order stream in the Sabarmati River basin (figure 1a) and drains into the alluvial plains of central Gujarat. Originating from the eastern hills of Panchmahal district comprising the rocks of Aravalli Super Group, the
Shedhi flows for a distance of about $50 \mathrm{~km}$ through the alluvial plain and joins the Vatrak River at Kheda (figure 1b). It follows a south-south westerly course and flows parallel to the Mahi River for a stretch of about $15 \mathrm{~km}$ in the upstream, however it takes a westerly trend in the lower reaches. Mohar Nadi, a tributary, meets the Shedhi at Nadiad. The river flows through two major geomorphic zones, viz., pediment zone and the alluvial zone (figure 1b). The pediment zone represents a dominantly planar surface with an average elevation between 60 and $80 \mathrm{~m}$ a.s.l. Deccan volcanics occur at shallow depths of 2-4 m and granites, limestones and sandstones as low outcrops in the pediment zone (Agarwal et al 1996). The alluvial zone which is covered by sandy soil represents an aggradational surface formed as a result of fluvial deposition by the major rivers and their tributaries. The basin provides a flat and featureless topography. The modern channel of Shedhi is very narrow (figure 2b) and covers an insignificant area of $1408 \mathrm{~km}^{2}$. The average annual discharge at Bilodra, which is located downstream of the study area is $50 \mathrm{~m}^{3} \mathrm{~s}^{-1}$. The channel comprises small and complex meanders with high sinuosity index (table 1). However, larger amplitude palaeomeanders can be observed along the course of the river (figure 2a, b). The channel width and the meander geometry is at a variance as defined by the established empirical relations. 

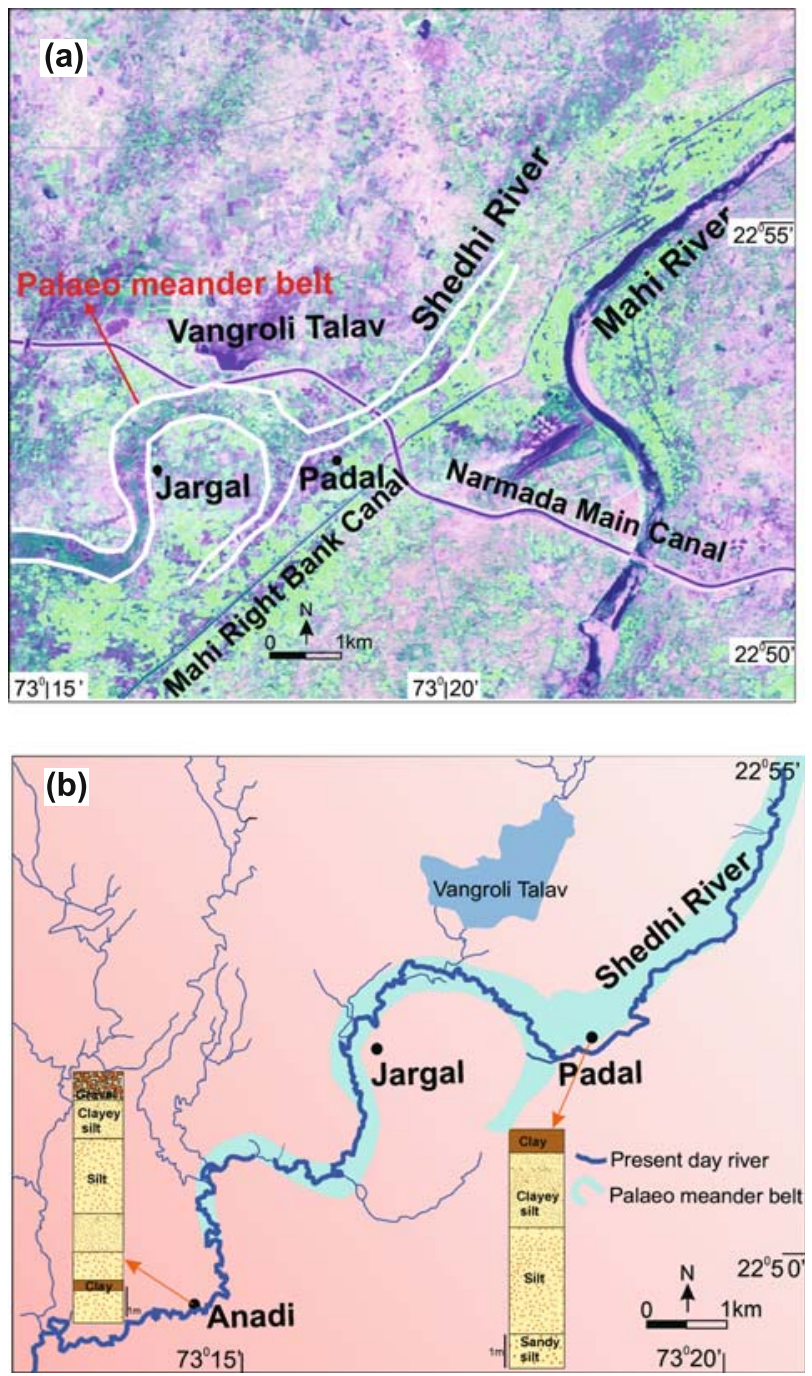

Figure 2. (a) The palaeomeander belt on IRS 1C, band 234 (2001) satellite data of the study area. (b) Palaeo and modern channel geometry of the Shedhi River. The lithologs represent the exposed section of the alluvial plain surface at Padal and of the terrace at Anadi.

\section{Palaeochannel geometry and discharge estimation}

A relationship exists between meander wavelength, channel width and discharge as also cross-section area and channel slope (Dury 1976). The above relationship, when applied, indicates that the channel with meander length $\left(L_{m}\right)$ of the order of $4500 \mathrm{~m}$ should be around $300 \mathrm{~m}$ wide (table 1 ). This is not the case with Shedhi River, suggesting that the large meanders are a result of a much wider palaeochannel with different discharge regime compared to the present. This is further substantiated by comparing the dimensions of the present and palaeochannel such as the width and depth as also the meander length, meander belt width and curvature which have been compared (table 1) and discharge quantifications made (table 2) applying the equations developed by Dury (1976); Williams (1978); Osterkamp and Hedman (1982) and Hodge and Tasker (1995). The planform analysis was carried out on a distinctly marked palaeomeander in the satellite data IRS 1C-Liss 3, band 234, 2001 (figure 2a). The palaeomeander was identified on the FCC by visual interpretation based on the tone and textural characteristics followed by a detailed field survey along the meander zone. The results indicate that the meander length $\left(L_{m}\right)$ of the palaeochannel was $4500 \mathrm{~m}(1500 \mathrm{~m}$ for the modern channel) and the width was $300 \mathrm{~m}(33 \mathrm{~m}$ for the modern channel). Decreases in width indicate decrease in discharge and/or decrease in coarse sediment load. The meander radius of curvature of the palaeochannel is also high $(950 \mathrm{~m})$ compared to the modern channel $(150 \mathrm{~m})$. In addition, the palaeochannel was entrenched, had a greater width-depth and meander width ratio than the modern channel (table 1). Width/depth ratio

Table 1. Planform characters of the palaeo and modern channel in the study area.

\begin{tabular}{lllll}
\hline $\begin{array}{l}\text { Channel planform } \\
\text { parameter }\end{array}$ & Relation used & $\begin{array}{l}\text { Palaeo } \\
\text { channel }\end{array}$ & $\begin{array}{l}\text { Present } \\
\text { channel }\end{array}$ \\
Meander length & $L_{m}(\mathrm{~m})$ & (Measured) & 4500 & 1500 \\
Radius of curvature & $\mathrm{R}(\mathrm{m})$ & (Measured) & 950 & 150 \\
Bankfull channel width & $W_{b}(\mathrm{~m})$ & $W_{b}=0.17 L_{m}^{0.89}$ & 300 & 114 \\
Channel width & $\mathrm{W}(\mathrm{m})$ & & - & 33 \\
Bankfull channel depth & $D_{b}(\mathrm{~m})$ & $D_{b}=0.027 L_{m}^{0.66}$ & 7 & 1.5 \\
& & $D_{b}=0.09 W_{b}^{0.59} \mathrm{Si}^{1.46}$ & 7.4 & 1.7 \\
Cross-section area & $\mathrm{Ac}\left(\mathrm{m}^{2}\right)$ & $A c=W_{b} D_{b}$ & 2100 & 50 \\
& & $A c=0.0054 L_{m}^{1.53}$ & 2098 & 47 \\
Slope & $\mathrm{S}(\mathrm{m} / \mathrm{km})$ & & & 1.11 \\
Width-depth ratio & & & 43 & 22 \\
Meander width ratio & & & 8.3 & 4.3 \\
Entrenchment ratio & $\mathrm{Si}$ & & 3.6 & 2.6 \\
Sinuosity index & & & 1.53 & 2.45 \\
\hline
\end{tabular}


Table 2. Discharge estimations for the palaeo and modern channel using channel dimensions.

\begin{tabular}{lllr}
\hline Equations & \multicolumn{1}{c}{ Developed by } & $\begin{array}{c}\text { Palaeo } \\
\text { channel }\end{array}$ & $\begin{array}{r}\text { Modern } \\
\text { channel }\end{array}$ \\
\hline $\begin{array}{l}Q=\left[(W / 2.99)^{1.81}+(L / 32.857)^{1.81}\right. \\
\left.\quad+0.83 A c^{1.09} \Omega\right] / 3\end{array}$ & Dury (1976) & 5623 & 125 \\
$\begin{array}{l}Q_{b}=9.93 A_{d}^{0.85} \\
Q_{b}=4.0 A_{b}^{1.21} S^{0.28}\end{array}$ & Dury (1976) & - & 238 \\
$\begin{array}{l}Q=0.027 W_{b}^{1.69} \\
Q=0.000017 L_{m}^{2.15}\end{array}$ & Williams (1978) & 6216 & 255 \\
$Q_{2}=1.88 A^{0.795} S^{0.113}$ & Osterkamp and Hedman (1982) & 415 & 10 \\
$Q_{2}=4.18 A^{0.669}$ & Carlston (1965) & 1215 & 6 \\
\hline
\end{tabular}

$Q$ - Average discharge; $Q_{b}$ - Bankfull discharge; $A_{d}$ - Drainage area; $A_{b}$ - Bankfull cross section area; $Q_{2}$ - Peak discharge for 2-year recurrence interval.
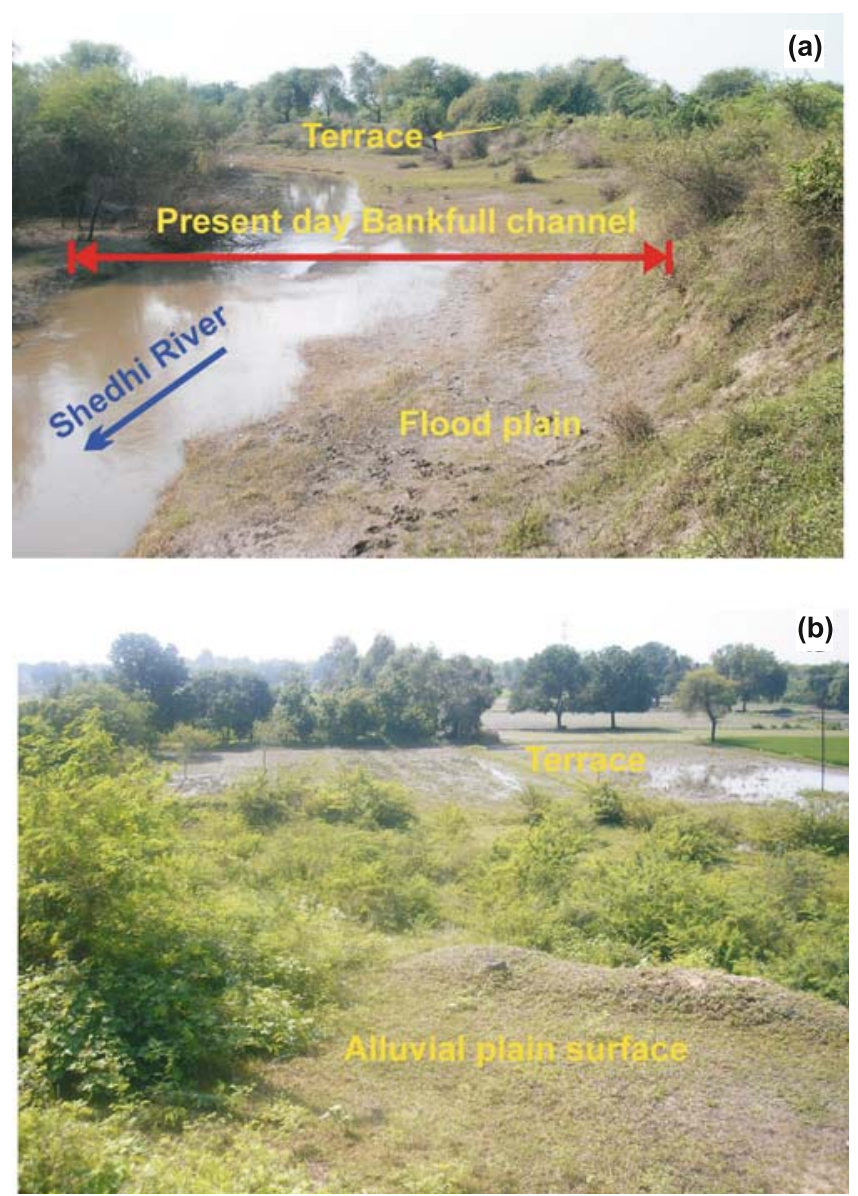

Figure 3. (a) A view of the Shedhi River showing the present day bankfull stage at Jargal. (b) A view along the Shedhi River exhibiting the terrace and the alluvial plain surfaces at Padal.

tends to increase with bank erosion and with higher coarse loads. Based on the channel morphology, bankfull discharge for the palaeochannel was estimated to be around $6000 \mathrm{~m}^{3} \mathrm{~s}^{-1}$ whereas the average discharge would have been around $400 \mathrm{~m}^{3} \mathrm{~s}^{-1}$ (table 2). Compared to this, for the modern channel, bankfull and average discharges are $200 \mathrm{~m}^{3} \mathrm{~s}^{-1}$ and $10 \mathrm{~m}^{3} \mathrm{~s}^{-1}$ respectively (table 2). However, in the absence of a discharge gauging station upstream on the study area, comparison between the estimations and the actual values is not possible. Similar estimations in the adjoining Mahi River (Alpa 2007) have been found to be in accordance with the recorded discharge. Considering the identical geomorphic setting of the Shedhi and the Mahi Rivers, it can be speculated that the above computation of palaeo and modern discharge are reasonable. Further, discharge is also a function of the drainage area for which an established relationship exists (Dury 1976). Application of the relationship to the modern and palaeochannel of the Shedhi River, reveals that the area drained by the palaeochannel was much larger $\left(\sim 2000 \mathrm{~km}^{2}\right)$ than the present drainage area.

\section{Discussion and conclusion}

The river channels undergo evolution in an effort to attain stability. Changes in stream types occur as the stream seeks a morphological form with greater stability or quasi-equilibrium. Rosgen (1996) has described the various stages of channel evolution and the type of streams that would result with change in the basin variables. Accordingly the modern Shedhi River appears to be Type E6 channel with very low width-depth ratio $(<12)$, high sinuosity $(>1.5)$, slope less than 0.02 and silt/clay channel material. The analysis of the palaeomeander however, reveals that the palaeochannel may have been a type C5 channel with high widthdepth ratio $(>12)$, moderate sinuosity $(>1.2)$, slope in the range of 0.001-0.02 and gravel/sand as channel material. The increasing sinuosity, decreasing slope and decreasing width-depth ratio can be attributed to the stream bank instability and related aggradation, thus resulting into stream 
type shift from earlier C5 to E6. This change occurs through a process of downcutting, bank erosion, and redeposition in the channel, and formation of a new bankfull capacity channel and active floodplain at a lower elevation (figure 3a). The floodplain is abandoned which now appears as a raised terrace (figure $3 \mathrm{~b}$ ) due to the incision (2$3 \mathrm{~m}$ ) and comprises silt and clay (figure 2b). Formation of terraces can be attributed to variations in the discharge/sediment yield ratio over time. These terraces abut against the incised $(\sim 6 \mathrm{~m})$ older alluvium (figure $3 \mathrm{~b}$ ) which has been assigned a late Pleistocene age (Merh and Chamyal 1997). In view of this, the palaeochannel of the Shedhi River should be younger and formed probably during the Holocene climatic optimum. The channel subsequently aggraded, raising the streambed elevation, increasing the width/depth ratio, and correspondingly decreasing the channel capacity. This can happen in a situation when the discharge is well regulated with strong seasonality (flooding) causing the bank erosion thus enhancing the sediment supply. The bank widening and fluvial aggradation is attributed to enhanced monsoon after the mid Holocene following the tectonically active phase of the early Holocene (Maurya et al 2000) in the uplands. The incision and narrowing of the channel to the present day dimensions would have occurred during dwindling hydrological condition (weak monsoon).

Discharge estimations for the palaeo and modern channel indicate that the bankfull palaeodischarge was almost 30 times more than the present day. In order to generate such large discharges in a comparatively limited drainage area, the precipitation must be orders of magnitude higher than the present day or the river should also have had a larger catchment. A similar estimate was obtained for the adjacent Mahi River during the mid-late Holocene (Alpa 2007).

Though this study is preliminary in nature, the reconstruction of palaeohydrological conditions based on geomorphic features enables the following inferences:

- The modern Shedhi River is a 'manifestly underfit' channel with a lower meander wavelength than the valley meander resulting due to reduced precipitation, shrinkage of drainage network and associated changes in the hydrologic conditions and sediment supply.

- Based on the palaeochannel morphology, the bankfull discharge was estimated to be around $6000 \mathrm{~m}^{3} \mathrm{~s}^{-1}$ whereas the average discharge would have been around $400 \mathrm{~m}^{3} \mathrm{~s}^{-1}$ which is around 30 times higher than the present.

- Episodes of lateral and vertical incision (widening and subsequent narrowing) are attributed to the changing monsoonal conditions during the Holocene.

\section{Acknowledgements}

The author is thankful to Prof. L S Chamyal for his invaluable help and guidance. Thanks are also due to Prof. V S Kale and Dr. N Juyal for peer reviews and constructive suggestions that improved the quality of the manuscript. Financial assistance provided by DST (Project No. DST/WOS-A/ES$35 / 2003)$ is gratefully acknowledged.

\section{References}

Agarwal R P, Dotiwala S, Mitra D S and Bhoj R 1996 The palaeodelta of the 'Proto' Vatrak and 'Proto' Mahi rivers of northeastern Gujarat, India: A remote sensing interpretation; Geomorphology 15 67-78.

Alpa Sridhar 2007 Mid-late Holocene hydrological changes in the Mahi River, arid western India; Geomorphology $\mathbf{8 8}$ 285-297.

Amsler M L, Carlos G R and Horacio A T 2005 Morphologic changes in the Parana river channel (Argentina) in the light of the climate variability during the $20^{\text {th }}$ Century; Geomorphology 70 1-22.

Callow J N and Smetten K R J 2006 Channel response to a new hydrological regime in southwestern Australia; Geomorphology $84254-276$.

Carlston C W 1965 The relation of free meander geometry to stream discharge and its geomorphic implications; $\mathrm{Am}$. J. Sci. $263864-885$.

Cremaschi M and Marchetti M 1995 Changes in fluvial dynamics in the central Po Plain (Italy) from late Pleistocene to early Holocene; In: European river activity and climatic change during the Lateglacial and early Holocene (ed.) Frenzel B, pp. 173-190.

Dury G H 1954 Bedwidth and wavelength in meandering valleys; Nature 17631.

Dury G H 1976 Change prediction, present and former, from channel dimensions; J. Hydrol. 30 219-245.

Eriksson M G, Olley J M, Kilham D R, Pietsch T and Wasson R J 2006 Aggradation and incision since the very late Pleistocene in the Naas River, south-eastern Australia; Geomorphology 81 66-88.

Hodge S A and Tasker G D 1995 Magnitude and frequency of floods in Arkansas; U.S Geological Survey WaterResources Investigations Report 95-4224, $52 \mathrm{p}$.

Kale V S, Ely L L, Enzel Y and Baker V R 1994 Geomorphic and hydrologic aspects of monsoon floods on the Narmada and Tapi rivers in central India; Geomorphology $10157-168$.

Kale V S, Joshi V U and Hire P S 2004 Palaeohydrological reconstructions based on analysis of a palaeochannels and Toba-Ash associated alluvial sediments in the Deccan Trap region, India; J. Geol. Soc. India 64 481-489.

Knox J C 1985 Responses of floods to Holocene climatic change in the upper Mississippi Valley; Quat. Res. 23 287-300.

Knox J C 1988 Climatic influence on upper Mississippi valley floods; In: Flood Geomorphology (eds) Baker V R, Kochel R C and Patton P C (New York: John Wiley) $357-376$.

Maurya D M, Rachna R and Chamyal L S 2000 History of tectonic evolution of Gujarat Alluvial Plains, Western 
India during Quaternary: A Review; J. Geol. Soc. India $55343-366$.

Merh S S and Chamyal L S 1997 The Quaternary geology of Gujarat alluvial plains; Proc. Indian Nat. Sci. Acad. $631-98$.

Osterkamp W R and Hedman E R 1982 Perennial streamflow characteristics related to channel geometry and sediment in Missouri River basin; USGS Prof. Paper 1242 $847-851$.

Patton P C and Baker V R 1977 Geomorphic response of central Texas streams to catastrophic rainfall and runoff; In: Geomorphology in Arid Regions (ed.) Doehring D O, Publications in Geomorphology, SUNY Binghamton, 189-217.

Rosgen D L 1996 Applied River Morphology; Wildland Hydrology Books, Pagosa, Springs, USA.

Roy N G and Sinha R 2005 Alluvial geomorphology and confluence dynamics in the Gangetic plains, Farrukhabad-
Kannauj area, Uttarpradesh, India; Curr. Sci. 89 2000-2006.

Schumm S A 1968 River adjustment to altered hydrologic regime-Murrumbidgee River and palaeochannels, Australia, US Geological Survey Professional Paper 598.

Sridhar V, Chamyal L S and Merh S S 1994 North Gujarat Rivers: Remnants of a Super Fluvial System; J. Geol. Soc. India 44 427-434.

Tinkler K J 1971 Active valley meanders in south-central Texas and their wider implications; Geol. Soc. Amer. Bull. 82 1783-1800.

Williams G P 1978 Bankfull discharge of rivers; Water Resource Research 114 1141-1154.

Williams G P 1988 Palaeofluvial estimates from dimensions of former channels and meanders; In: Flood Geomorphology, (eds) Baker V R, Kochel R C and Patton P C (New York: John Wiley) 321-334. 